\title{
Replik på Wästerfors debattartikel
}

\author{
GUNNAR ALSMARK
}

David Wästerfors artikel om konsten att intervjua chefer väcker många tankar - och ett och annat höjt ögonbryn. Min första reaktion var: usch så naivt och elementärt. Även efter en andra genomläsning kvarstod min kritik, om än i något mildare form. Jag finner det därför angeläget att diskutera det ämne Wästerfors tar upp, att intervjua chefer, dels på ett mer principiellt plan, dels mer knutet till intervjuobjektet i sig, cheferna.

Min första fråga är: för vem skriver David Wästerfors? Är det verkligen för den kvalificerade publik som läser Socialvetenskaplig tidskrift? Tveksamt, med tanke på de mångasjälvklarheter och plattityder artikeln är tryfferad med.

Hur bör en chef intervjuas? Frågan kan tyckas banal, inleder Wästerfors med. Men vem tycker så? Knappast ens Wäster-

Gunnar Alsmark är docent på etnologiska institutionen vid Lunds universitet. Han arbetar också sedan många år på Institut for arkaeologi og etnologi i Köpenhamn. Hans huvudsakliga forskningsfält är internationell migration och etniska relationer (IMER) med betoning på rasism och främlingsfientlighet, integrationsproblematiken samt massmedias roll i formandet av det mångkulturella Sverige. Sedan slutet av 60-talet har Alsmark ägnat materialinsamling via olika former av intervjuer, samtal och deltagarobservation stort utrymme i sin forskning. fors själv, som menar att det »under vissa omständigheteru krävs en särskild metod, eller medvetenhet, när man intervjuarchefer. Men varför bara under vissa omständigheter. Om vi tänker bort ordet metod, som är alldeles för pretentiöst $i$ detta sammanhang (det blir inte en ny metod bara för att man väljer att vara lite mer aktiv), så kräver alla intervjuer en särskild medvetenhet. I den bemärkelsen är det ingen skillnad om man som forskare intervjuar en fiskare i Bohuslän, en flykting från Somalia, en journalist på Dagens Nyheter eller en chef på Ericsson. En medvetenhet om det aktuella ämnesområdet (havsfiske, flyktingskap etc), om intervjusituationen i sig, och inte minst, om den egna rollen som forskare, insatt i en reflexiv process. Vem är jag som intervjuar? Vilka är mina förutfattade meningar och kulturbundna synsätt? Hur ser mina ideologiska och politiska blockeringar ut?

\section{Vattentäta skott?}

Wästerbergs egen förförståelse och erfarenhet hade det varit intressant att få veta något om. Är han lika okunnig i ämnet som han verkar? Eller har han bara valt fel nivå, språkligt och innehållsmässigt? För t.ex. en etnolog eller en antropolog, där mjukdata via 
intervjuer varit ett viktigt källmaterial i snart nog ett halvt sekel, blir man minst sagt förvånad när Wästerberg påstår, att sociologer förmodligen är relativt ensamma i sitt metodologiska betraktande av intervjun. Ett betraktande som ofta kännetecknas av en hög grad av självmedvetenhet och en nästan ritualiserad självkritik.

Ett sådant förmätet påstående kräver en mer allmän kommentar. Det tydliggör de närmast vattentäta skott som finns mellan många grannvetenskaper på universitetet. Efter mer än tio års arbete i olika tvärvetenskapliga forskargrupper har jag sett hur viljan att veta vad andra gör, och har gjort, växlar högst betydligt. Många uppfinner hellre hjulet en gång till än att "gå till grannen", så att säga. Särskilt vanlig är denna hållning bland sociologer vis-à-vis etnologer, det vågar jag nog påstå, utan att för den skull dra alla över en kam. „Vad kan en sociolog lära av en etnolog", var den retoriska frågan jag fick från en sociolog från Umeå på en IMER-konferens här för leden.

Varje gång jag hör en sådan patriarkalisk, grötmyndig hållning blir jag missmodig. Självklart skall vi förhålla oss kritiska till olika sidor inom varandras discipliner. Men att för den skull per definition förkasta ett helt universitetsämne är olyckligt. Och i grunden rätt barnsligt, faktiskt.

Dessutom är det en hållning som är svår att upprätthålla i en postmodern vetenskapstradition, vars själva kärna utgör en kritik mot att det finns ett slags rationella helhetslösningar och förklaringar. Denna "representationens problematik" handlar i korthet om språketsoch forskarensmöjligheter att avbilda en yttre verklighet (Alvesson/ Sköldberg 1994). Och den borde stämma till större ödmjukhet ämnesrepresentanter emellan än vad man fortfarande möter.

Varken förtal eller förtigande är bra strategier.

\section{Vem kan vad?}

Mina kommentarer har inget med "surt sa räven" att göra, om nu någon tror det. Kritiken bottnar i en önskan att lyfta fram det gränsöverskridande i forskningsprocessen. Om jag som t.ex. sociolog, psykolog, pedagog eller ekonomhistoriker vill intervjua chefer, vilka har då gjort spännande forskning att ta spjärn mot? Och vilka är duktiga på intervjuteknik, på mjuka data? Efter att ha läst Wästerfors artikel gick mina tankar osökt till Mats Lindqvists mycket intressanta bok Herrar $i$ näringslivet. Om kapitalistisk kultur och mentalitet (1996). Den utgör en slutrapport från flera års studier av toppdirektörernas värld, där vi får möta högröstade och ständigt leende herrar som talade om börskurser och synergieffekter, men också lära känna de gloriösa framstegens osnygga bakgård där förödmjukelser, konkurser och häxjakter grasserar.

Boken påminner oss om att konsten att intervjua chefer i grunden handlar om kunskap och förförståelse, något jag redan berört. Den tekniska sidan, själva intervjusituationen, är i sig viktig, men hänger intimt samman med ledet före - och efter - i den vetenskapliga processen. Vilka frågor bör och förmår - jag ställa? Vilken syn har jag på chefer allmänt - och politiskt/ideologiskt? Hur skall den färdiga texten se ut? I vilken språklig form vävs chefernas svar in? Kommer deras kommentarer att komplementeras med annat material? 
Om detta nämner Wästerfors inget. Reflektioner kring hur chefer bör intervjuas blir enbart en metod, ett samtal här och nu, utan för- eller efterhistoria. Den för Wästerfors viktiga frågan handlar om huruvida man som intervjuare skall förhålla sig aktiv eller passiv. Med stöd av Holstein \& Gubrium kritiserar han den missvisande distinktionen mellan snaturligar och sonaturligar samtal. Intervjun skall i stället betraktas som ett socialt möte, där kunskap konstrueras snarare än inhämtas eller avslöjas.

Kritiken är viktig, men knappast ny. Wästerfors slår in öppna dörrar för alla de humanister och samhällsvetare, som $i$ åratal arbetat med kvalitativa metoder och reflexivitet. Inte minst inom sociologi och socialt arbete. För att nu inte tala om min egen disciplin.

När den internationella debatten om reflexivitet i humanvetenskaperna, om hur forskaren hanterar sin subjektivitet och sin egen personliga närvaro i studiet av andra människor, tog fart i början av 80-talet, startades snabbt en fruktbar debatt inom nordisk etnologi och folkloristik. På min egen institution i Lund utvecklades kulturanalys som ett särskilt sätt att se på och tolka den omvärld man skulle utforska. Hur gjorde man det till synes självklara och vardagsnära spännande och intressant? Vilka frågor exotiserade materialet, och lockade fram ny och annorlunda kunskap?

Att forskaren hela tiden var en aktiv del av denna kunskapsprocess var självklart. Jag kan inte minnas att ordet passiv, än mindre objektiv figurerade i våra diskussioner. Att Wästerfors ännu 25 år senare behöver ta utgångspunkt i dikotomin aktiv-passiv har nog att göra med den positivistiska/ naturvetenskapliga grundsyn som så länge domineratsvensksamhällsvetenskap.En syn som, med Holstein \& Gubriums ord, först med en postmodern fokusering på representationsproblematiken ledde till ett ifrågasättande av den konventionella synen på intervjun som ett oproblematiskt och transparent kunskapsmedium. Eller som Gunnela Westlander säger $i$ en relativt nyutkommen antologi om Kvalitativa metoder $i$ arbetslivsforskning. "Metodmässigt plöjdes ett huvudspår och resultaten gjorde anspråk på att leverera verklighetsbilder" (1999:16). Man skulle också kunna lägga till att tankemässigt vilar samhällsvetenskapligt tänkande fortfarande tungt på en tradition, där dikotomier, dualismer och motsatspar spelar stor roll. Världen begreppsliggörs ofta viapolaritetersomnatur/kultur,tro/vetande, manligt/kvinnligt, subjekt/objekt, vara/böra, individ/samhälle, förstålförklara, centrum/ periferi,som Miegel/Schoug(1999) påpekari antologin Dikotomier. Wästerfors begreppspar aktiv-passiv, liksom hans fyrfältstänkande, hör hemma i detta i dag allt mer ifrågasatta synsätt.

För mig som är skolad i en fenomenologisk forskningstradition minns jag hur märkligt svårt det var att under 70- och 80-talen föra fram kritik mot standardiserade frågeformulär och ambitiöst formulerade mätinstrument. Kanske därför att kritiken kom från "fel« håll, men också därför att många samhälls- och beteendevetare så starkt trodde på att man med rätt metoder kunde spegla en verklighet.

Ett bevis på detta är den nyss nämnda antologin om kvalitativa metoder i arbetslivsforskningen. Den bygger på en arbetskonferenskring temat kvalitativa forsknings- 
ansatser, som Rådet för arbetslivsforskning arrangerade i januari 1999. Konferensen skall ses som ett första steg $i$ vidareutvecklingen av områdetsäger Gunnel Färm, rådets generaldirektör. För dem som vill ha en mångsidig perspektivering på temat kan jag varmt rekommendra boken. En annan bok väl värd att nämna är Mats Alvessons och KajSködbergs Tolkningoch reflektion. Vetenskapsfilosofi och kvalitativ metod (1994). Från det i sig självklara att data alltid är tolkade, alltid konstruerade mot bakgrund av personliga, kulturella, ideologiska och språkliga referensramar fördjupar de diskussionen kring begreppet reflektion. Ordet innebär att ta ett steg bakåt från tolkningen, att tolka sina egna tolkningar, att perspektivera sina egna perspektiv. Det som gör boken intressant i detta sammanhang är att författarna navigerar i friutrymmet mellan den abstrakta filosofin och den metodologiska »kokboken", där Wästerfors befinner sig. Hantverksinriktad litteratur av teknisk, konkret art har självklart sin funktion att fylla, men vadden kvalitativa metoden framför allt behöver är en kritisk diskussion av begrepp (som t.ex. hermeneutik, diskursanalys, dikotomi, genealogi) samt en intellektualisering mer allmänt.

En viktig del i denna intellektualisering handlar om etik. Här vill jag nämna Bente Gullveig Alver och Örjar Öyens Etik och praktik i forskarens vardag (1997). I boken diskuteras etiska överväganden i forskningsprocessen. Frågan vilkaavvägningarär rimliga $i$ balansen mellan önskan att vinna ny kunskap och människans rättigheter till autonomi och integritet vrids och vänds på genom en lång rad exempel. Det hade inte varit fel om Wästerfors åtminstone antytt att frågan existerar. En chef vid mikrofonen bör väcka en lång rad etiska spörsmål hos varje seriös forskare.

\section{En chef är en chef är en chef}

Skriver man må vara en aldrig så kort artikel om konsten att intervjua chefer tycker jag att det vore rimligt att ägna åtminstone några rader åt vad man menar med chef. Är begreppet så entydigt som Wästerfors tycks mena? Att vara chef för ett storföretag i näringslivet, ett departement, en social myndighet, en skola, ett familjeföretag, en städfirma, en institution på universitetet - skillnaderna blir rätt stora. Könsrollsperspektivet hade också varit värt en rad eller två. Det enda i denna väg vi får veta är att det inte alltid behöver vara riktigt så enkelt att intervjuaren i varje tillfälle är underordnad den intervjuade chefen. Och att man därmed heller inte kan ta för givet att varje chef agerar dominerande och självsäkert. Men nog bör man väl fråga sig om sambandet överordnad $=$ dominerande och självsäker är så givet?

Det övergripande problemet med Wästerfors reflektioner kring hur chefer bör intervjuas är att de är för få, för enkla, och för kokbokspräglade. Man tar en chef, en aktiv intervjuare, blandar hur- och vad-frågor i lagom proportioner - och vips får man en spännande och intressant anrättning.

Nåja, nu hårddrar jag medvetet. Riktigt så enkelt menar inte heller Wästerfors att det är. Men hans försök till modellbygge överskuggar de nyanseringar som också görs. Särskilt när dessa blir alltför självklara, för att inte säga aningslösa. Eller vad sägs om 
följande mening. I stället för att en gång för alla definiera maktrelationen mellan en chef och en forskare kan ett kontextuellt och textuellt perspektiv anläggas. Relationen beror sannolikt på i vilket sammanhang intervjun äger rum

Varför bara sannolikt? Varje intervju är väl präglad av sitt sammanhang och av de ämnen som tas upp? Jag förstår helt enkelt inte hur Wästerfors tänker och om han är den novis i ämnet han låter förmedla genom sin artikel. I så fall rekommenderar jag honom att botanisera lite mer i den uppsjö av böcker om intervjuteknik och narration som finnsi sociologinsmjuka grannvetenskaper.

\section{Litteratur}

Alvesson Mats, Sköldberg Kaj, 1994: Tolkning och reflektion. Vetenskapsfilosofi och kvalitativ metod. Lund: Studentlitteratur

Alver Bente Gullveig, Øyen Ørjar, 1997: Etik och praktik i forskarens vardag. Lund: Studentlitteratur.

Lindqvist Mats 1996: Herrar i näringslivet. Om kapitalistisk kultur och mentalitet. Stockholm: Natur och Kultur.
Lindén Jitka, Westlander Gunnela, Karlsson Gunnar, 1999: Kvalitativa metoder i arbetslivsforskning. 24 forskare visar hur och varför. Uppsala: Rådet för arbetslivsforskning.

Miegel Fredrik, Schoug Fredrik, 1999: Dikotomier. Vetenskapsteoretiska reflektioner. Lund: Studentlitteratur. 